\title{
An unexpected Rearrangement of Dimethyl-Al- lyl-2-Hydroxyethyl Quaternary Ammonium Salts in an Alkaline Medium
}

\author{
G H Torosyan* \\ National polytechnic university of Armenia, Armenia
}

Submission: January 25, 2018; Published: January 29, 2018

"Corresponding author: Gagik Torosyan, Doctor of Chemical sciences, National Polytechnic University of Armenia, Armenia, Tel: 0037493 998830; Email: gagiktorosyan@seua.am

\section{Short Communication}

It's known intramolecular 0-benzylation of dimethylbenzyl2-hydroxyethylammonium chloride at $175-180^{\circ} \mathrm{C}$ with the formation of dimethylaminoethanol benzyl ether chlorohydrate with a low yield - 5-20\% [1]. The same salt undergoes to Sommelet rearrangement in a strong alkaline medium with the formation of corresponding tertiary amine [2].

It's known also that containing an allyl or benzyl group serve as alkylating agents due to the easy cleavage of these groups [3].

There are presented the results about behavior of $\mathrm{N}, \mathrm{N}$-dimethyl-N-allyl-N-2-hydroxymethyl ( DMAHMAmBr) ammonium bromide in alkaline solution.

Heating of DMAHMAmBr at $100-105^{\circ} \mathrm{C}$ in a two-phase "liquid-liquid" catalytic system with one time distillation of water and the resulting light-boiling products leads to the formation of dimethylallylamine (way A) and dimethyl-2-allyloxyethylamine (way B)with yields of 30 and $22 \%$, respectively.

Heating of DMAHMAmBr over the powdered alkali leads to the same products with yields of 11 and $35 \%$, respectively, as well as the croton condensation product of penten-4-al (way A). The same Quat in the presence of powdered alkali in dry toluene splits along path a to form dimethylamylamine (yield 93\%) and acetylene (way A).

The amyl analogue of these salt in the same conditions gives $\mathrm{N}, \mathrm{N}$-dimethyl-N- amyl amine and acetylene ( way A) (Figure 1).

The benzyl analogue of these salt is cleaved analogously DMAHMAmBr, but in a low yield for the $\mathrm{N}, \mathrm{N}$-dimethyl-Nbenzyloxyethylamine obtained $(11 \%)$. The results obtained testify to the intramolecular transition of the allyl and benzyl groups from the nitrogen atom to oxygen. The structure synthesized products were proved by IR, UV, 1HNMR and Mass spectrometry.

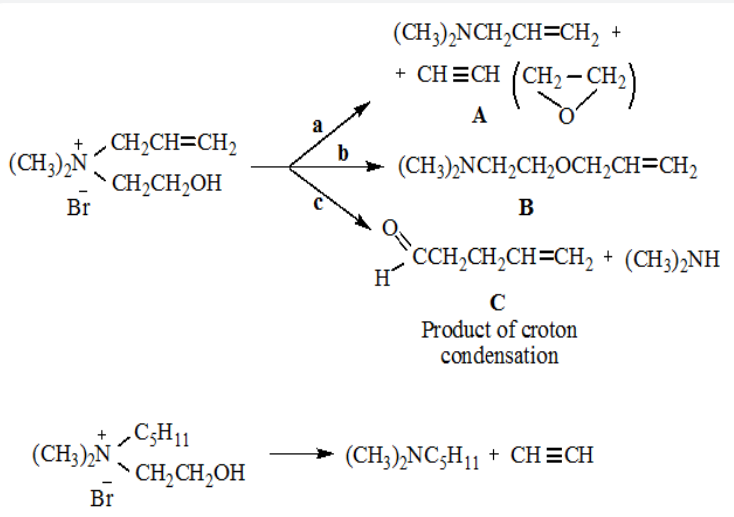

(Figure 1).

\section{References}

1. SG Kuznetsov, SM Chigareva (1970) Rearrangement of dimethylbenzyl2-hydroxyethylammonium chloride. Journal Organic chemistry 6(4): 881-882.

2. CC Jones, ChR Hauser (1962) Ortho-substituted rearrangement vis elimination of quaternary ammonium ion- and diethyl ether with excess of sodium amide. Journal Organic chemistry 27(3): 806-814.

3. MG Indjikyan, SA Surmanyan, AT Babayan (1957) On the strength of the connection in some quaternary ammonium salts-Izv. AS of ASSR 10(3): 213-221. 
(C) (1) This work is licensed under Creative

BY DoI: 10.19080/OMCIJ.2018.05.555658

\section{Your next submission with Juniper Publishers will reach you the below assets}

- Quality Editorial service

- Swift Peer Review

- Reprints availability

- E-prints Service

- Manuscript Podcast for convenient understanding

- Global attainment for your research

- Manuscript accessibility in different formats ( Pdf, E-pub, Full Text, Audio)

- Unceasing customer service

Track the below URL for one-step submission https://juniperpublishers.com/online-submission.php 